\title{
Bongardia chrysogonum (L.) Spach as a potential medicinal plant against cancer and Alzheimer's disease management
}

\author{
Sevgi Gezici1 ${ }^{1 *}$ (D), Nazım Șekeroğlu 2,3 (D) \\ 'Kilis 7 Aralik University, Faculty of Science and Literature, Department of Molecular Biology and Genetics, Kilis, Turkey \\ ${ }^{2}$ Kilis 7 Aralik University, Application and Research Center (ATARC), Advanced Technology, Kilis, Turkey \\ ${ }^{3}$ Kilis 7 Aralik University, Faculty of Agriculture, Department of Horticulture, Kilis, Turkey
}

ORCID IDs of the authors: S.G. 0000-0002-4856-0221; N.Ș. 0000-0002-0630-0106

Cite this article as: Gezici, S., \& Sekeroglu, N. (2021). Bongardia chrysogonum (L.) spach as a potential medicinal plant against cancer and Alzheimer's disease management. Istanbul Journal of Pharmacy, 51 (3), 319-325.

\begin{abstract}
Background and Aims: Bongardia chrysogonum (L.) Spach (Berberidaceae), an ancient medicinal plant in Eastern Mediterranean countries, is traditionally used for the treatment of epilepsy, hemorrhoids, urinary system infections and gastrointestinal disorders. This study was designed to evaluate potential neuroprotective and anticancer effects of different parts from B. chrysogonum.

Material and Methods: Leaf, stem, and tuber parts of the plant were extracted and subjected to determine cholinesterase enzyme inhibitory potentials and anticancer activities. Enzyme inhibition assays were carried out to screen neuroprotective potentials, while the MTT assay was performed for evaluating anticancer activities of the extracts towards human lung carcinoma (A549), breast adenocarcinoma (MCF-7), brain glioma (C6), and non-tumorous human umbilical vein endothelial cell (HUVEC) lines.

Results: Among the tested extracts, the highest enzyme inhibitory activity was exhibited by tuber-water extract $(83.81 \pm 0.33 \%$ and $62.14 \pm 0.60 \%$ inhibition on $\mathrm{AChE}$ and $\mathrm{BChE}$ at $400 \mu \mathrm{g} / \mathrm{mL} p<0.01$, respectively), whilst the lowest enzyme inhibition was exerted by the tuber-chloroform extract. Moreover, the tuber part of the plant was found to have the most cytotoxic activity against all the cancer cells, and the best anticancer activity was determined in tuber ethanol extract against MCF-7 cells $\left(I C_{50}=28.36 \pm 0.04, \mathrm{p}<0.01\right)$.

Conclusion: To the best of our knowledge, this research is the first study that assessed the in vitro neuroprotective effect of the aerial parts and tuber extracts of the plant through inhibition of cholinesterase enzymes alongside an anticancer capacity towards human cancer cells. The results revealed that this plant is a good candidate for performing further clinical studies in cancer and neurodegenerative diseases.
\end{abstract}

Keywords: Bongardia chrysogonum (L.) Spach, cancer, enzyme inhibition, medicinal plant, neuroprotection

\section{INTRODUCTION}

Medicinal plants used in traditional medicine are well-known to have numerous pharmacological actions and extraordinary therapeutic potentials in the prevention and cure of several diseases, particularly oxidative stress related-diseases including diabetes, hypertension, atherosclerosis, cancer, ischemia, multiple sclerosis, cardiac hypertrophy, amyotrophic lateral sclerosis, Alzheimer's, and Parkinson's diseases (Fang et al., 2017; Ismail, Amanat, lqbal \& Mirza, 2018; Gezici \& Sekeroglu 2019a; Ahmad, Waheed, Rozeen, Mahmood \& Kamal, 2019. Moreover, medicinal plant-derived natural compounds serve as a therapeutic alter-

Address for Correspondence:

Sevgi GEZici, e-mail: drsevgigezici@gmail.com, sevgigezici@kilis.edu.tr

This work is licensed under a Creative Commons Attribution 4.0 International License. 
native for combating cancer and neurodegenerative disorders, owing to rich phytochemical contents and natural antioxidant potentials (Safarzadeh, Shotorbani \& Baradaran, 2014; Chen, Lin, Dong, Zhang \& Du, 2018; Sahoo, Dandapat, Dash \& Kanhar, 2018; Gezici \& Sekeroglu, 2019b). According to statistical data, there has been a great increase in Alzheimer's disease (AD) incidence around the world, from this point of view, finding effective and safe therapy approaches have an accountable role to manage the high incidence of this disease. On the other hand, cholinergic-based therapy that means inhibition of the level of some enzymes including acetylcholinesterase (AChE) and butyrylcholinesterase (BChE) seems to be as one of the most effective treatment strategies for the AD pathogenesis (Ismail et al., 2018; Harris, 2019; Gezici, 2018). In this concern, medicinal plants and natural products have been gaining interest among the researchers almost all over the world. Thus, the researchers have focused on the development of novel plant-derived natural products with less or no side effects as well as unlimited availability.

The genus Bongardia L. (Berberidaceae), native to the Eastern Mediterranean region, is represented by only one species (Bongardia chrysogonum) in the flora of Turkey. This species is generally known as 'Uruf-el-Deek' and locally known as 'catlak otu' in Anatolia, which is distributed in the Eastern Mediterranean region, North America, Jordan, Afghanistan, Syria, Iran, Iraq, Azerbaijan, and Turkey. Tubers of this plant have been mainly used in folk remedy since ancient times (Karl \& Strid, 2009; Abuhamdah et al., 2017a; Abuhamdah et al., 2017b). From the past to today, scientific records have stated that the tubers of $B$. chrysogonum have been utilized for the treatment of epilepsy and hematological malignancies in the form of decoction (23\%) around Afghanistan, Iran, Jordan, Syria, and Turkey by the local rural communities. The tubers have also been reported to be used in order to treat gastrointestinal disorders, urinary tract infections, prostate hypertrophy, hypercholesterolemia, hemorrhoids, and diabetes, because of their antidiarrheal, antimicrobial, antiulcerogenic, anticonvulsant, and antioxidative activities (Alfatafta, Abu Zarga, Sabri, Freyer \& Shamma, 1989; Baydoun, Chalak, Dalleh \& Arnold, 2015; Dokuyucu et al., 2016; Abuhamdah et al., 2017a; Abuhamdah et al., 2017b).

Recent studies reported the antioxidant and anti-convulsant activities of the tuber extracts of $B$. chrysogonum (Abuhamdah et al., 2017a; Abuhamdah et al., 2017b). However, the other biological activities have not been identified using each part of this plant, yet. In this context, extracts of the aerial parts (leaf and stem, individually) and tuber of B. chrysogonum extracted by using different solvents including ethanol, water, and chloroform were screened for revealing potential anticancer and neuroprotective capacities in the presented work. The neuroprotective potential of the extracts was evaluated through AChE and BChE inhibitory activities. The MTT assay was performed for determining cytotoxic and anticancer activities of the extracts against cells; A549 (human lung carcinoma), MCF7 (human breast adenocarcinoma), C6 (human brain glioma), and non-tumorous HUVEC (human umbilical vein endothelial cells), in a concentration and time dependently.

\section{MATERIALS AND METHODS}

\section{Chemicals and equipment}

5,5-dithio-bis-2-nitrobenzoic acid (DTNB), ethanol (EtOH), methanol $(\mathrm{MeOH})$, chloroform $\left(\mathrm{CHCl}_{3}\right)$, dimethyl sulfoxide (DMSO), neocuproine, ammonium acetate $\left(\mathrm{NH}_{4} \mathrm{Ac}\right), \mathrm{AChE}$ (electric eel acetylcholinesterase, Type-VI-S, EC 3.1.1.7), BChE (horse serum butyrylcholinesterase, EC 3.1.1.8), acetylthiocholine iodide (ATCI), butyrylthiocholine chloride (BTCI), sodium dihydrogen phosphate $\left(\mathrm{NaH}_{2} \mathrm{PO}_{4}\right)$, sodium bicarbonate $\left(\mathrm{NaHCO}_{3}\right)$, and reference standards were purchased from Sigma (St. Louis, MO, USA). Cell culture mediums and chemicals were purchased from ThermoFisher Scientific, Gibco ${ }^{\circ}$. A Microplate reader spectrophotometer from Thermo Lab systems (408 Multiskan) was used to measure the absorbance.

\section{Collection of plant material}

The plant sample used in this study was collected from its natural habitat from the Gaziantep province (Turkey) in April, 2018. The plant species was identified by Res. Assist. Fatih Yayla, a taxonomist from the Department of Biology, Gaziantep University, Gaziantep (Turkey). A voucher specimen (number: GAUN1603) was deposited at the Herbarium of Department of Biology, Gaziantep University, Turkey (Figure 1).

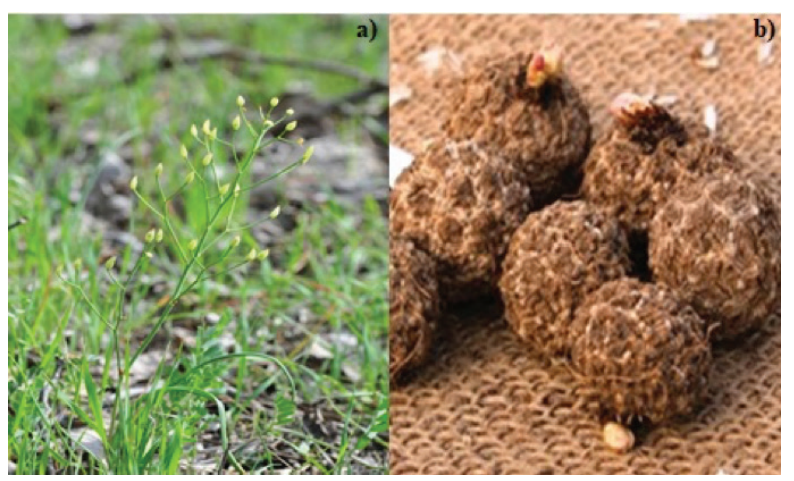

Figure 1. Bongardia chrysogonum a) aerial parts, b) tuber.

\section{Preparation of the extracts}

The air-dried plant material including the tuber and aerial parts (leaf and stem) of B. chrysogonum was extracted with 70\% ethanol $(\mathrm{EtOH})$, distilled water $\left(\mathrm{dH}_{2} \mathrm{O}\right)$, and chloroform $\left(\mathrm{CHCl}_{3}\right)$ for two days at room temperature as described in the previous publications (Gezici \& Sekeroglu, 2019a; Gezici, 2019). After the extraction procedures, the extracts were deposited at $-20^{\circ} \mathrm{C}$ until further analysis.

\section{AChE and BChE enzyme inhibitory studies}

The Neuroprotective potential of the extracts expressed as their inhibitory activity against cholinesterase enzymes (AChE and BChE) was determined by as described by Ellman, Courtney, Andres \& Featherstone, (1961) and all conditions were similar to that described previously (Senol, Sekeroglu, Gezici, Kilic \& Orhan, 2018; Sekeroglu \& Gezici, 2019). The reaction was observed at $412 \mathrm{~nm}$ utilizing a microplate reader spectrophotometer, using galanthamine as the reference drug. 
The percent inhibition of the enzymes was calculated by a comparison of reaction rates in the extract with a blank sample using the formula as given below:

Percentenzyme inhibition (\%) $=($ Aenzyme-Asample $) /$ Aenzyme $\times 100$

[Where $A_{\text {enzyme }}$ is the activity of enzyme without the extract, and $A_{\text {sample }}$ is the activity of enzyme with the extract].

\section{Anticancer activity studies}

\section{Cell lines and cultures}

A549 (lung carcinoma), MCF-7 (breast adenocarcinoma), C6 (brain glioma), and non-tumorous HUVEC (human umbilical vein endothelial cells) cell lines, obtained from the American Type Culture Collection (ATCC, USA) were used to determine the in vitro anticancer effects of $B$. chrysogonum extracts. The lung carcinoma cell was cultured on Roswell Park Memorial Institute Medium (RPMI), supplemented with 10\% (v/v) fetal bovine serum (FBS), antibiotics $(1 \%, 100 \mathrm{U} / \mathrm{ml}$ penicillin and $100 \mu \mathrm{g} / \mathrm{ml}$ streptomy(in), and L-glutamine (1\%) in the flasks at $37^{\circ} \mathrm{C}$ in a humidified $\mathrm{CO}_{2}(5 \%)$ incubator. MCF-7, C6, and HUVEC cells were grown in Dulbecco's modified Eagle medium (DMEM): Ham's F12 nutrient medium (1:1) with the same additives. All the assays were carried out in triplicate using the cell lines from passage 24 or less.

\section{MTT anticancer activity assay}

To evaluate the cytotoxic potentials of the extracts, the MTT (3-(4,5-dimethylthiazol-2-yl)-2,5-diphenyltetrazolium bromide) assay was performed as described by Mosmann (1983) with a minor modification (Gezici, Sekeroglu \& Kijjoa, 2017; Gezici, 2019). Briefly, densities of $5 \times 10^{3}$ cells were seeded in $200 \mu \mathrm{l}$ medium into 96-well plates for 24 hrs and after seeding, the extracts with concentrations from $50 \mu \mathrm{g} / \mathrm{mL}$ to $400 \mu \mathrm{g} / \mathrm{mL}$ were added into all the wells, and then they incubated at $37^{\circ} \mathrm{C}$ for $48 \mathrm{hrs}$. After incubation, the medium was discarded and 50 $\mu \mathrm{L} /$ well of MTT (Sigma-Aldrich) solution $(5 \mathrm{mg} / \mathrm{mL}$ ) was added into each well and incubated for 4 hrs at $37^{\circ} \mathrm{C}$. The mediumcontaining MTT was discarded and $200 \mu \mathrm{L}$ of DMSO added for both lysis the cells and solubilization formazone. Then, the absorbance was measured at $570 \mathrm{~nm}$ with a Thermo Lab system 408 Multiskan multiplate spectrophotometer. The doseresponse curve was used to generate the $\mathrm{IC}_{50}(\mu \mathrm{g} / \mathrm{mL})$ values, and doxorubicin used as the reference.

\section{Statistical analysis}

The experiments were carried out in triplicate and data were presented as mean \pm S.D. values $(n=3)$. A linear regression analysis was conducted for generating $I_{50}$ values. ANOVA (one way) was used for the evaluation of statistical differences between the control and the sample groups. A $p$ value of $<0.05$ was examined to be significant, and $p<0.01$ was considered to be very significant statistically $\left({ }^{*} p<0.05,{ }^{* *} p<0.01\right)$.

\section{RESULTS}

\section{AChE and BChE enzyme inhibitory results}

All the extracts from the leaf, stem, and tuber of B. chrysogonum were evaluated for their inhibitory activities against AChE and BChE enzymes at 50, 100, 200, and $400 \mu \mathrm{g} / \mathrm{mL}$ concentrations, and galanthamine was used as the reference drug (Table 1). As

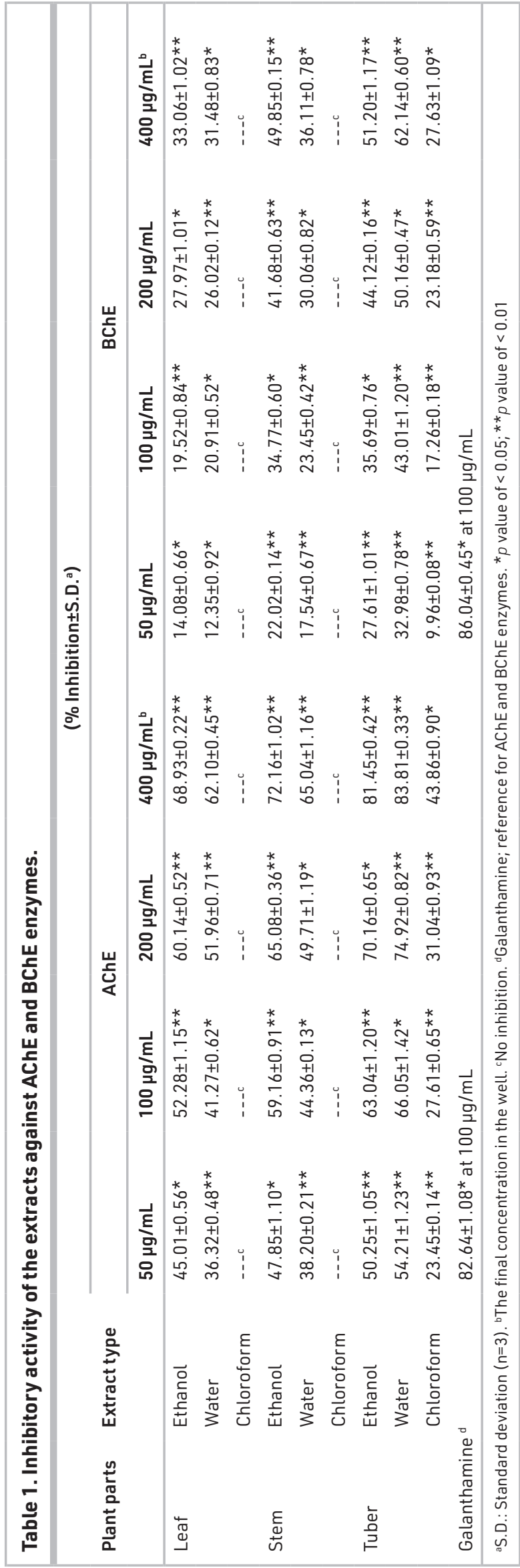


summarized in Table 1, the extracts tested herein demonstrated from moderate to a high level of inhibition against the abovementioned enzymes. The extracts inhibited AChE at high levels, whilst they inhibited BChE at moderate levels (below 50\%). Although a significant variation was not assessed among the tested extracts, the tuber water extract showed a significant inhibition against $A C h E$ and $B C h E(83.81 \pm 0.33 \%$ and $62.14 \pm 0.60 \%$, respectively) at $400 \mu \mathrm{g} / \mathrm{mL}$. The tuber chloroform extract was exerted the lowest enzyme inhibition through AChE and BChE $(43.86 \pm 0.90 \%$ and $27.63 \pm 1.09 \%$, respectively), and the chloroform extracts from leaves and stems were also observed to be ineffective in inhibiting both cholinesterase. In the assay, the water extracts from the leaves and stems exhibited moderate inhibitory activities on both AChE and BChE enzymes in the range of $31.48 \pm 0.83 \%$ and $65.04 \pm 1.16 \%$ as compared to those of the ethanol extracts (Table 1).

\section{Anticancer activity results against human cancer cells}

The cytotoxic effects of the mentioned plant parts of $B$. chrysogonum were assessed against A-549, MCF-7, and C6 cancer cells, in comparison to non-tumour HUVECs. The tested extracts exerted a noteworthy cancer prevention potential against the cancer cells in a dose and time dependent manner; however, the $\mathrm{IC}_{50}$ values were varied depending on the cancer cells and plant parts. The results were expressed as $I C_{50}(\mu \mathrm{g} /$ $\mathrm{mL}$ ) values after $72 \mathrm{hrs}$ treatment period at $200 \mu \mathrm{g} / \mathrm{mL}$ concentration (Table 2).

As concluded from the $\mathrm{IC}_{50}$ values given in Table 2 , the tuber part of the plant was found to possess higher cancer prevention potentials, when compared to those of the aerial parts. In all cases, all plant parts caused a much more cytotoxicity on MCF-7 cells, while they exhibited lower effects against C6 cells. On the other hand, the tuber $\mathrm{EtOH}$ extract showed the best

Table 2. Anticancer activities of the extracts against A549, MCF-7, and C6 human cancer cells.

\begin{tabular}{|c|c|c|c|}
\hline Human cancer cells & \multicolumn{2}{|c|}{ Plant parts Extract type } & \multirow{2}{*}{$\begin{array}{l}\text { IC }_{50} \text { values }^{\mathrm{a}}(\mu \mathrm{g} / \mathrm{mL}) \\
190.66 \pm 1.47^{\star}\end{array}$} \\
\hline \multirow{9}{*}{ A549 } & \multirow{3}{*}{ Leaf } & Ethanol & \\
\hline & & Water & $145.02 \pm 0.96^{* *}$ \\
\hline & & Chloroform & $228.16 \pm 1.03^{*}$ \\
\hline & \multirow{3}{*}{ Stem } & Ethanol & $235.16 \pm 1.92 * *$ \\
\hline & & Water & $201.80 \pm 2.07^{*}$ \\
\hline & & Chloroform & $280.94 \pm 0.39 *$ \\
\hline & \multirow{3}{*}{ Tuber } & Ethanol & $147.01 \pm 0.82$ ** \\
\hline & & Water & $80.06 \pm 1.25^{\star *}$ \\
\hline & & Chloroform & $178.12 \pm 1.94^{* *}$ \\
\hline \multirow{9}{*}{ MCF-7 } & \multirow{3}{*}{ Leaf } & Ethanol & $74.48 \pm 1.01 *$ \\
\hline & & Water & $98.07 \pm 0.19 *$ \\
\hline & & Chloroform & $129.35 \pm 0.43^{* *}$ \\
\hline & \multirow{3}{*}{ Stem } & Ethanol & $174.27 \pm 0.92$ ** \\
\hline & & Water & $191.95 \pm 2.06^{* *}$ \\
\hline & & Chloroform & $237.03 \pm 2.54^{*}$ \\
\hline & \multirow{3}{*}{ Tuber } & Ethanol & $28.36 \pm 0.04^{* *}$ \\
\hline & & Water & $61.23 \pm 1.10^{* *}$ \\
\hline & & Chloroform & $69.72 \pm 0.38 * *$ \\
\hline \multirow{9}{*}{ C6 } & \multirow{3}{*}{ Leaf } & Ethanol & $285.24 \pm 0.68^{* *}$ \\
\hline & & Water & $259.09 \pm 2.06^{*}$ \\
\hline & & Chloroform & $306.75 \pm 1.94^{* *}$ \\
\hline & \multirow{3}{*}{ Stem } & Ethanol & $286.10 \pm 0.71 *$ \\
\hline & & Water & $262.55 \pm 1.32 * *$ \\
\hline & & Chloroform & $321.68 \pm 2.14^{*}$ \\
\hline & \multirow{3}{*}{ Tuber } & Ethanol & $240.92 \pm 1.19 * *$ \\
\hline & & Water & $214.50 \pm 0.25^{* *}$ \\
\hline & & Chloroform & $287.01 \pm 0.52 * *$ \\
\hline \multicolumn{3}{|l|}{ Doxorubicin ${ }^{b}$} & $7.96 \pm 0.18$ \\
\hline \multicolumn{3}{|c|}{ DMSO (dimethyl sulfoxide) ${ }^{c}$} & 0 \\
\hline
\end{tabular}


anticancer activity $\left(\mathrm{IC}_{50}=28.36 \pm 0.04 \mu \mathrm{g} / \mathrm{mL}, p<0.01\right)$ towards MCF-7 human cancer cells, when the stem chloroform extract was found to have the weakest anticancer activity against C6 cells $\left(\mathrm{IC}_{50}=321.68 \pm 2.14 \mu \mathrm{g} / \mathrm{mL}, p<0.05\right)$. As for the extraction type, the water extracts obtained from any part of the plant demonstrated the highest anticancer activity towards A549 and C6 cancer cells. However, the EtOH extracts owned the highest cancer prevention capacities against MCF-7 cells, whereas the chloroform extracts showed the lowest ones in all cases.

\section{DISCUSSION}

Acetylcholinesterase (AChE), butyrylcholinesterase (BChE) and tyrosinase (TYR) enzymes involved in neurodegenerative mechanisms have been reported to be associated with pathogenesis of neurodegeneration and neurodevelopmental diseases such as Alzheimer's disease (AD), Parkinson's disease (PD), Huntington's disease (HD), amyotrophic lateral sclerosis (ALS), prion diseases, attention deficit hyperactivity disorder (ADHD), and autism spectrum disorder (ASD). Of which, AD is known as the most common type of neurodegenerative disorder leading to a loss of memory and behavior skills in the elderly (Alamgir, 2017; Ismail et al., 2018; Ahmad et al., 2019. A number of medicinal plants and plant-derived compounds have been reported to inhibit AChE and BChE, involved in the acetylcholine and butyrylcholine hydrolysis, respectively, which is the most accepted drug treatment strategy in patients with AD (Grutzendler \& Morris, 2001; Sekeroglu et al., 2012; Gezici \& Sekeroglu, 2019a). From this point, the inhibition of key enzymes linked to the pathogenesis of the AD and PD diseases used medicinal plant and plantderived compounds are suggested as one of the most effective strategies. For example, the inhibition of AChE and BChE, involved in the acetylcholine and butyrylcholine hydrolysis, respectively is the most accepted treatment strategy in $A D$. Additionally, the inhibition of TYR alongside cholinesterase (ChE) is of great importance for the treatment of these diseases as multi-target drug approaches (Sekeroglu et al., 2012; Santos, Gomes, Pinto, Camara \& Paes, 2018; Gezici \& Sekeroglu, 2019a; Gezici \& Sekeroglu, 2021).

In our ongoing research on finding natural enzyme inhibitors, neuroprotective potentials of $B$. chrysogonum extracts through $\mathrm{AChE}$ and BChE enzyme inhibition were aimed to screen in this work. Based on the results of cholinesterase enzyme inhibition, the tested extracts of the plant were found to exhibit a promising enzyme inhibitory effect towards both $\mathrm{AChE}$ and BChE, which are closely associated with $A D$ development. Probably, these strong enzyme inhibition potentials of this plant may be due to the presence of rich secondary metabolites including bongardine, N-acetyl bongardine, bongardol, bongardol acetate, and bongardamine, as reported by previous studies (Alfatafta et al., 1989; Rahman et al., 1998; Shahwar, Choudhary, Sener, Toker \& Baser, 1999; Rahman et al., 2000; Karl \& Strid, 2009). In addition, alkaloids are important secondary metabolites for cholinesterase inhibition. Previous studies showed that this plant is also rich for isoquinoline alkaloids like retuculine, coclaurine etc. (Al- fatafta et al., 1989; Abuhamdah et al., 2017a; Abuhamdah et al., 2017b).

The increasing cancer burden worldwide requires an alternative treatment solution. Plants have been used for medicinal purposes since times immemorial, and these plants and natural compounds isolated or extracted from the medicinally important plants offer a very viable alternative in the treatment and management of several cancer types (Roleira et al., 2015; Gezici \& Sekeroglu, 2019b; Khan et al., 2020). Based on their traditional uses and experimental evidences, cancer prevention potentials of $B$. chrysogonum were analyzed in the presented research. Particularly, the tuber parts of B. chrysogonum extracts prepared using different solvents demonstrated a good level of anticancer effects against the tested cancer cells. According to the anticancer activity results, increasing concentration of the extracts resulted in a decrease in the number of cancer cells, likewise, an increasing exposure time resulted in a significant inhibition of cell growth in the cancer cells. It is clearly proven that the plant could have a noteworthy potential as an anticancer agent for the management of reducing the number of cancer cells and suppressing the cell growth in cancer. In the light of the literature, the notable cancer prevention effects of $B$. chrysogonum are most likely due to the fact that it has rich phytochemical contents such as isoquinoline alkaloids and triterpenoid saponins as revealed previously (Alfatafta et al., 1989; Rahman et al., 1998; Shahwar et al., 1999; Rahman et al., 2000; Karl \& Strid, 2009).

Although, 2,2-diphenyl-1-picrylhydrazyl (DPPH) and hydroxyl $(\cdot \mathrm{OH})$ free radical scavenging activities of the tuber part of $B$. chrysogonum have been demonstrated by a few previous studies until now (Dokuyucu et al., 2016; Abuhamdah et al., 2017a; Abuhamdah et al., 2017b), there has been no research conducted for the evaluation of anti-cholinesterase and anticancer effects using individually each part of B. chrysogonum in the literature. Therefore, to the best of our knowledge, the assessment of in vitro neuroprotective and cancer preventive potentials of different plant parts of $B$. chrysogonum were performed for the first time in the current research.

\section{CONCLUSION}

To summarize, the probable in vitro neuroprotective capacities and anticancer effects of the ethanol, water, and chloroform extracts from different parts of B. chrysogonum (L.) Spach were evaluated the first time in the current study. The results obtained exhibited that the tuber part of the plant has the greatest biomedical potential through its significant inhibitory activities on the tested enzymes related to $A D$ and also a remarkable cancer prevention activity against A549, MCF-7, and C6 cancer cells. These findings could be of valuable scientific evidence to contribute to the pharmaceutical industry in the prevention and treatment of AD and cancer; however, detailed mechanisms based in vitro and in vivo studies are necessary in future. Besides, in order to specify the phytochemicals responsible for notable neuroprotective effect and cancer prevention capacity of the plant-extracts, phytochemistry of the extracts should be analyzed as further research. 
Peer-review: Externally peer-reviewed.

Author Contributions: Conception/Design of Study- S.G.; Data Acquisition- S.G., N.S.; Data Analysis/Interpretation- S.G., N.S.; Drafting Manuscript- S.G., N.S.; Critical Revision of Manuscript- N.S.; Final Approval and Accountability- S.G., N.S.

Conflict of Interest: The authors have no conflict of interest to declare.

Financial Disclosure: This study was financially supported by the Scientific Research Project Unit of Kilis 7 Aralik University, Kilis - Turkey (Project code no: 11911/1828MAP1).

Acknowledgements: The authors would like to thank Genetics Laboratory, Advanced Technology Application and Research Center, Kilis 7 Aralik University for technical support. The authors are also grateful to Res. Assist. Fatih Yayla for identifying and Biologist Didem Kocum for providing the plant material.

\section{REFERENCES}

- Abuhamdah, S., Abuirmeile, A. N., Thaer, F., Al-Olimat, S., Abdel, E., \& Chazot, P. L. (2017a). Anti-convulsant effects of Bongardia chrysogonum L. tuber in the pentylenetetrazole-induced seizure model. International Journal of Pharmacology, 14(1), 127-135. https:// doi.org/10.3923/ijp.2018.127.135.

- $\quad$ Abuhamdah, S., Shatarat, A., Al-Essa, M., Al-Ameer, H., Al-Olimat, S., \& Chazot, P. (2017b). Spasmolytic and antimicrobial activities of crude extract of Bongardia chrysogonum L. tubers. International Journal of Pharmacology, 14(1), 52-60. https://doi.org/10.3923/ijp.2018.52.60.

- $\quad$ Ahmad, S. S., Waheed, T., Rozeen, S., Mahmood, S., \& Kamal, M. A. (2019). Therapeutic study of phytochemicals against cancer and Alzheimer's disease management. Current Drug Metabolism, 20(13), 1006-1013. https://doi.org/10.2174/13892002216662001 03092719.

- $\quad$ Alamgir, A.N.M. (2017). Therapeutic use of medicinal plants and their extracts: volume 1: pharmacognosy. K.D. Rainsford (Ed.), Progress in Drug Research 73, Springer International Publishing AG. https://doi.org/10.1007/987-3-319-63862-1.

- Alfatafta, A. A., Abu Zarga, M. H., Sabri, S. S., Freyer, A. J., \& Shamma, M. (1989). An investigation of Bongardia chrysogonum. Journal of Natural Products, 52(4), 818-821. https://doi.org/10.1021/ np50064a024.

- $\quad$ Baydoun, S., Chalak, L., Dalleh, H., \& Arnold, N. (2015). Ethnopharmacological survey of medicinal plants used in traditional medicine by the communities of Mount Hermon, Lebanon. Journal of Ethnopharmacology, 173, 139-156. https://doi.org/10.1016/j.jep.2015.06.052.

- Chen, L., Lin, L., Dong, Z., Zhang, L., \& Du, H. (2018). Comparison of neuroprotective effect of Forsythia suspensa leaf extract and forsythiaside, one of its metabolites. Natural Product Research, 32(22), 2705-2708. https://doi.org/10.1080/14786419.2018.1514401.

- Dokuyucu, R., Gozukara, K. H., Ozcan, O., Sefil, N. K., Nacar, A., Dokuyucu, A., \& Inci, M. (2016). The effect of Bongardia chrysogonum on prostate tissue in a rat model of STZ-induced diabetes. SpringerPlus, 5(1), 1-7. https://doi.org/10.1186/s40064-016-2973-z.

- Ellman, G. L., Courtney, K. D., Andres Jr, V., \& Featherstone, R. M. (1961). A new and rapid colorimetric determination of acetylcholinesterase activity. Biochemical Pharmacology, 7(2), 88-95. https://doi.org/10.1016/0006-2952(61)90145-9.

- $\quad$ Fang, J., Wang, L., Wu, T., Yang, C., Gao, L., Cai, H., ... \& Wang, Q. (2017). Network pharmacology-based study on the mechanism of action for herbal medicines in Alzheimer treatment. Journal of Ethnopharmacology, 196, 281-292. https://doi.org/10.1016/j. jep.2016.11.034.
- Gezici, S., Sekeroglu, N., \& Kijjoa, A. (2017). In vitro anticancer activity and antioxidant properties of essential oils from Populus alba $L$. and Rosmarinus officinalis L. from South Eastern Anatolia of Turkey. Indian Journal of Pharmaceutical Education and Research, 51(3), 498-503. https://doi.org/10.5530/ijper.51.3s.74.

- Gezici, S. (2018). Promising anticancer activity of lavender (Lavandula angustifolia Mill.) essential oil through induction of both apoptosis and necrosis. Annals of Phytomedicine, 7(2), 38-45. https://doi.org/10.21276/ap.2018.7.2.55.

- Gezici, S. (2019). Comparative anticancer activity analysis of saffron extracts and a principle component, crocetin for prevention and treatment of human malignancies. Journal of Food Science and Technology, 56(12), 5435-5443. https://doi.org/10.1007/ s13197-019-04014-y.

- Gezici, S., \& Sekeroglu, N. (2019a). Neuroprotective potential and phytochemical composition of acorn fruits. Industrial Crops and Products, 128, 13-17. https://doi.org/10.1016/j.indcrop.2018.10.082.

- $\quad$ Gezici, S., \& Sekeroglu, N. (2019b). Current perspectives in the application of medicinal plants against cancer: novel therapeutic agents. Anti-Cancer Agents in Medicinal Chemistry, 19(1), 101-111. https://doi.org/10.2174/1871520619666181224121004.

- Gezici, S., \& Sekeroglu, N. (2021). Comparative biological analyses on kenger and kenger coffee as novel functional food products. Journal of Food Science and Technology, 1-11. https://doi. org/10.1007/s13197-021-05248-5.

Grutzendler, J., \& Morris, J. C. (2001). Cholinesterase inhibitors for Alzheimer's disease. Drugs, 61(1), 41-52. https://doi. org/10.2165/00003495-200161010-00005.

- Harris, R. E. (2019). Epidemiology of chronic disease: global perspectives. (chapter 48, pp. 753-769). Second Edition, Jones \& Bartlett Learning.

- Ismail, H., Amanat, M. A., lqbal, A., \& Mirza, B. (2018). Medicinal plants: a complementary and alternative antidepressant therapy. Current Pharmaceutical Design, 24(22), 2609-2624. https://doi.org/ 10.2174/1381612824666180727123950.

Karl, R., \& Strid, A. (2009). Bongardia chrysogonum (Berberidaceae) rediscovered on the East Aegean island of Chios. Phytologia Balcanica, 15, 337-342. https://citeseerx.ist.psu.edu/viewdoc/downl oad?doi=10.1.1.482.7088\&rep=rep1\&type $=$ pdf.

Khan, T., Ali, M., Khan, A., Nisar, P., Jan, S. A., Afridi, S., \& Shinwari, Z. K. (2020). Anticancer plants: A review of the active phytochemicals, applications in animal models, and regulatory aspects. Biomolecules, 10(1), 47. https://doi.org/10.3390/biom10010047.

Mosmann, T. (1983). Rapid colorimetric assay for cellular growth and survival: application to proliferation and cytotoxicity assays. Journal of Immunological Methods, 65(1-2), 55-63. https://doi. org/10.1016/0022-1759(83)90303-4.

Rahman, A. U., Shahwar, D., Parween, Z., Choudhary, M. I., Sener, B., Toker, G., \& Can Baser, K. H. (1998). New alkaloids from Bongardia chrysogonum. Natural Product Letters, 12(3), 161-173. https://doi. org/10.1080/10575639808048287.

- Rahman, A.U, Shahwar, D., Choudhary, M.I., Sener, B., Toker, G., \& Baser, K.H.C. (2000). Triterpenoid saponins from Bongardia chrysogonum. Journal of Natural Products, 63(2), 251-253. https://doi. org/10.1021/np9801312.

Roleira, F. M., Tavares-da-Silva, E. J., Varela, C. L., Costa, S. C., Silva, T., Garrido, J., \& Borges, F. (2015). Plant derived and dietary phenolic antioxidants: Anticancer properties. Food Chemistry, 183, 235-258. https://doi.org/10.1016/j.foodchem.2015.03.039.

- Safarzadeh, E., Shotorbani, S. S., \& Baradaran, B. (2014). Herbal medicine as inducers of apoptosis in cancer treatment. Advanced Pharmaceutical Bulletin, 4(1), 421. https://doi.org/10.5681/ apb.2014.062. 
- Sahoo, A. K., Dandapat, J., Dash, U. C., \& Kanhar, S. (2018). Features and outcomes of drugs for combination therapy as multi-targets strategy to combat Alzheimer's disease. Journal of Ethnopharmacology, 215, 42-73. https://doi.org/10.1016/j.jep.2017.12.015.

- $\quad$ Santos, T. C. D., Gomes, T. M., Pinto, B. A. S., Camara, A. L., \& Paes, A. M. D. A. (2018). Naturally occurring acetylcholinesterase inhibitors and their potential use for Alzheimer's disease therapy. Frontiers in Pharmacology, 9, 1192. https://doi.org/10.3389/fphar.2018.01192.

- Sekeroglu, N., \& Gezici, S. (2019). Astragalus neurocarpus Bioss. as a potential source of natural enzyme inhibitor associated with Alzheimer's and Parkinson diseases along with its rich polyphenolic content and antioxidant activities. Annals of Phytomedicine, 8(1), 82-87. https://doi.org/10.21276/ap.2019.8.1.9.
Sekeroglu, N., Senol, F. S., Orhan, I. E., Gulpinar, A. R., Kartal, M., \& Sener, B. (2012). In vitro prospective effects of various traditional herbal coffees consumed in Anatolia linked to neurodegeneration. Food Research International, 45(1), 197-203. https://doi. org/10.1016/j.foodres.2011.10.0088.

- Senol, F. S., Sekeroglu, N., Gezici, S., Kilic, E., Orhan, I. E. (2018). Neuroprotective potential of the fruit (acorn) from Quercus coccifera $\mathrm{L}$. Turkish Journal of Agriculture and Forestry, 42(2), 82-87. https://doi. org/10.3906/tar-1711-18.

- Shahwar, D., Choudhary, M. I., Sener, B., Toker, G., \& Baser, K. H. C. (1999). Alkaloids of Bongardia chrysogonum. Phytochemistry, 50(2), 333-336. https://doi.org/10.1016/S0031-9422(98)00484-1. 